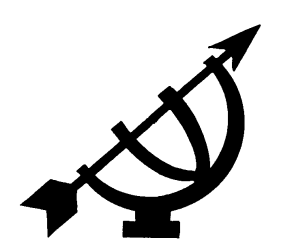

\title{
Ouers se rol in die oordrag van etiese en morele waardes
}

\author{
Tom Larney \& George A. Lotter \\ Skool vir Kerkwetenskappe \\ Potchefstroomkampus \\ Noordwes-Universiteit \\ POTCHEFSTROOM \\ E-pos: fpbtl@puk.ac.za \\ kwsgal@puk.ac.za
}

\begin{abstract}
Parental role in the transmission of ethical and moral values

The primary focus of this article is to describe the characteristics and nature of the process of transmitting moral and ethical values from parents to children. The transmission of values within the framework of parents and family implies a horizontal as well as a vertical dimension. The role of parents and family can, however, not be evaluated in isolation. On a horizontal level the influence of philosophical trends and traditions, psychological theories, time-determined attitudes and social conditions are thus scrutinised in order to understand reality and different perspectives on man's position in this world. In particular structuralistic and psychoanalytic views, as well as social determinants in the transmission of values, are discussed. Parents' task as educators is also seen from the specific perspective of parental role in the process of instruction, parents' modelling function and the influence of world view and attitude in transmitting moral and ethical values. In conclusion the vertical dimension of value transmission is also indicated: the influence of and the way in which children internalise religious values and a sense of religiosity is thus established.
\end{abstract}

\section{Opsomming}

Ouers se rol in die oordrag van etiese en morele waardes

Die primêre fokus van hierdie artikel is om die eienskappe en aard van die proses te beskryf waardeur morele en etiese waardes van ouers na kinders oorgedra word. Waarde-oordrag binne die raamwerk van die ouerlike rol en die gesinsopset 
impliseer 'n horisontale sowel as 'n vertikale dimensie. Die rol van ouers en die gesinsopset kan egter nie in isolasie beoordeel word nie. Op 'n horisontale vlak word die invloed van filosofiese rigtings en tradisies, psigologiese teorieë, tydsbepaalde uitgangspunte en sosiale omstandighede dus van nader beskou. Strukturalistiese en psigoanalitiese benaderings asook sosiale determinante wat geld in die oordrag van waardes, word in die besonder bespreek. Ouers se taak as opvoeders word ook beskryf vanuit die perspektief van spesifiek die ouerlike rol in die proses van onderrig, ouers se modelleringsfunksie en die invloed van wêreldbeskouing en -houding in die proses van waarde-oordrag. Ten slotte word die vertikale dimensie van waarde-oordrag betrek: die invloed van en wyse waarop kinders godsdiensbepaalde waardes internaliseer en hulle godsdienssin uiteindelik gevestig en versterk word.

\section{Inleiding en prinsipiële begronding}

Die maniere waarop morele en etiese waardes binne gesinsverband oorgedra word, kan vanuit verskillende benaderingshoeke geskied. Binne 'n Christelike gemeenskap sal die lig wat die Skrif werp op die plek van die gesin en die verantwoordelikheid van ouers in die opvoeding en geloofsontwikkeling van hulle kinders ongetwyfeld beskou word as van primêre belang. Tog moet in aanmerking geneem word dat die oordra van waardes 'n vertikale én 'n horisontale dimensie het. Vir Christenouers is die vertikale dimensie baie belangrik. In 'n opvoedingsituasie wat spesifiek daarop afgestem is om waardes te vestig, is hulle ook besig met die grondliggende taak om die bestaan van geloof in die lewe van hulle kinders te vestig. Binne 'n Christelike beskouing word aanvaar dat ouers nie hulle kinders se geloof kan vorm nie: ouers se lewe en getuienis kan egter grootliks bydra dat hulle kinders se geloof gevestig word en stewige ankers verkry. Vir Christenouers sal die oordra van waardes gegrond word op die besef dat die mens ' $n$ beelddraer is - die nadruk op 'n eties en moreel aanvaarbare lewenswyse word dus gerig vanuit die besef dat die mens se lewe in ooreenstemming met die bedoeling van die Skepper moet wees. Wanneer die klem in die oordrag van morele en etiese waardes egter hoofsaaklik vanuit humanistiese oorwegings geskied, sal die horisontale dimensie in waarde-oordrag uiteraard benadruk word.

\section{Metode en verantwoording}

In hierdie artikel word hoofsaaklik gefokus op afleidings uit die verskillende filosofiese denkrigtings waar dit oor die oordrag van waardes handel, asook op mensbeskouings vanuit verskillende 
teologiese tradisies. Op grond van die ondersoek van hierdie aspekte, word in die slotgedeelte van die artikel gekyk na die rol van die gesin in die morele en etiese ontwikkeling van kinders, asook na die raakpunt wat dit het met die godsdienstige ontwikkeling van kinders.

\section{Ouers se rol in die morele en etiese ontwikkeling van die kind}

Alhoewel die oordra van morele waardes of die beoefening van etiese gedrag in sy breedste sin nie sonder meer met godsdiensbeoefening of met bepaalde godsdienstige opvattings gelykgestel kan word nie, kan verwantskappe tog bestaan tussen hierdie aspekte en die rol wat die gesin in die bevordering van godsdiensbepaalde waardes speel. Die uitgebreide konseptuele sowel as empiriese aandag wat steeds aan hierdie aspek gegee word, laat iets blyk van die belang wat aan waarde-oordrag geheg word. ${ }^{1}$ In die publikasies wat in voetnoot 1 genoem word, word uitgebreid besin oor die wyse waarop morele waardes by die individu in die kinderjare gevorm word.

In die inleidende deel van hierdie artikel word waardes en die oordrag daarvan in 'n breë algemene sin behandel - veral soos dit beskryf word deur verskillende filosofiese denkskole en sosiale en psigologiese teorieë. Die laaste deel van die artikel fokus meer in besonderhede op godsdiensbepaalde waardes. Vir die doeleindes van hierdie artikel word onder etiese en morele waardes die volgende verstaan: riglyne vir die neem van verantwoordbare en aanvaarbare besluite oor jouself, jou plek in 'n gemeenskap en in die wêreld - besluite en gedragswyses wat met integriteit teenoor jouself en teenoor ander rolspelers geneem word. Religieuse waardes impliseer daardie gedragswyse wat gerig word deur die besef dat jou lewe ondergeskik staan aan 'n hoër mag. Vir die gelowige impliseer hierdie besef die uitlewing van Skrifbegronde riglyne en die erkenning van die transendentale. Laasgenoemde tipe waardes sal beslis bydra tot godsdiensontwikkeling en 'n godsdiensbepaalde gedragswyse.

Die rol van ouers, hetsy in samewerking met ander entiteite soos portuurgroepe, of ondergeskik aan ander invloede, is onbetwisbaar

1 Vergelyk onder andere in hierdie verband die sienings van Walker, Hennig en Krettenauer (2000); White (2000); White en Matawie (2004); Knafo en Schwartz (2003). 
belangrik in die oordra van waardes in 'n algemene, maar ook in 'n spesifiek religieuse sin.

Die ontwikkeling van beskouings oor invloede en prosesse wat ' $\mathrm{n}$ rol speel in die oordra van waardes, is onder andere die resultaat van bepaalde filosofiese uitgangspunte wat oor jare ontwikkel het. Terselfdertyd kom sielkundige benaderings wat veral in die twintigste eeu op verskillende tye en wyses die besinning oor hierdie onderwerp oorheers het, na vore.

\subsection{Filosofiese perspektiewe}

Soos Grusec (1997:3-4) aantoon, was daar binne verskillende filosofiese tradisies van die vroegste tye af intense besinning oor die morele ontwikkeling van die mens en veral oor die wyse waarop waardes van een geslag na die volgende oorgedra word. Veral filosofiese besinnings binne die Westerse tradisie het die intellektuele ruimte geskep wat moderne teorieë oor die oordrag van morele waardes beïnvloed het. Grusec onderskei in hierdie opsig drie perspektiewe op die oordrag van morele waardes (wat nie noodwendig opeenvolgend is nie):

\subsubsection{Beskouings oor die basiese aard van die mens}

- Die Joods-Christelike perspektief - inherente verdorwenheid

Die vraag oor hoe morele waardes ontwikkel het of die wyse waarop dit van geslag tot geslag oorgedra word, moet noodwendig berus op of verband hou met beskouings oor die basiese aard van die mens. Hieroor het die opvatting oor die inherente verdorwenheid van die mens, soos dit in die Joods-Christelike teologie gegrondves is, lank 'n bepalende rol gespeel. Grusec (1997:3) toon aan hoe die spore van hierdie beskouing terug te vind is in die opvattings van sulke uiteenlopende groepe of individue soos Hobbes, die Puriteine en John Wesley. Volgens Grusec (1997:4) kan 'n minder ekstreme vorm van hierdie beskouing selfs nagespeur word in die moderne psigoanalise, wat die siening onderskryf dat die jong kind deur die id gedomineer word en instinktiewe begeertes het wat onmiddellike bevrediging vereis.

\section{- Kinders se inherente deugdelikheid}

Radikaal teenoor die opvatting van inherente verdorwenheid, staan die opvatting dat jong kinders inherent goed en deugdelik is (Grusec, 1997:4). Hierdie beskouing het sy oorsprong by die Switsers-Franse filosoof, Jean-Jacques Rousseau, wat die gemeenskap verantwoordelik gehou het vir die morele degenerering 
van die individu. In die twintigste eeu het hierdie beskouing veral gemanifesteer in die opvattings van Jean Piaget en sy navolgers. Die siening dat kinders inherent goed en deugdelik is, vind steeds op meer of minder wetenskaplike gronde neerslag in benaderings dat kinders meer verstaan en minder gedissiplineer moet word. Ook word benadruk dat kinders, namate hulle ouer word, toegelaat moet word om met ouers te onderhandel (Grusec, 1997:4).

\section{- Kinders as 'n tabula rasa}

In die lig van die bostaande twee sienings is die derde en amper onvermydelike benadering oor die morele status van kinders dié dat hulle nóg kwaad, nóg goed is. Kinders word naamlik beskou as 'n skoon lei of tabula rasa waarop geskryf kan en moet word (Grusec, 1997:4). Hierdie siening verteenwoordig veral die benadering van die 17de-eeuse Engelse filosoof, John Locke. Vandag nog word die perspektief dat die kind 'n tabula rasa is, gevind in die behaviouristiese benadering, wat die kind sien as die resultaat of produk van 'n verskeidenheid leerervarings.

\subsection{Wetenskaplike modelle vir die evaluering van morele ontwikkeling}

Elkeen van die breë filosofiese benaderings wat hierbo genoem is, impliseer in een of ander mate die betrokkenheid en verantwoordelikheid van ouers by die opvoeding van kinders en die oordrag van morele waardes. Tog dui Walker (1999:261) aan dat wat die morele opvoeding van kinders betref - die ouer se rol vir 'n groot deel van die twintigste eeu inderwaarheid na die kantlyn uitgeskuif is. Hy skryf hierdie toedrag van sake toe aan die huidige era se periodieke oorheersende invloed van veral een van die belangrike psigologiese benaderings tot waardevorming en -oordrag, naamlik die kognitiewe ontwikkelingsbenadering, of soos dit ook bekend staan, die strukturalistiese benadering. Naas hierdie benadering staan ook twee ander benaderings wat 'n groter rol aan ouers toeken, naamlik die strukturalistiese beskouing en die beskouing dat 'n mens sosiaal "leer".

\subsubsection{Die strukturalistiese beskouing}

Die strukturalistiese beskouing of benadering het vir 'n groot gedeelte van die twintigste eeu die navorsing en ontwikkeling op die gebied van waardevorming en -oordrag gedomineer. Volgens Windmiller (1980:2) het hierdie benadering veral sy oorsprong in die Kantiaanse beskouing dat die individu 'n self-organiserende entiteit is wat grootliks op grond van sy eie optrede ontwikkel. Hierdie 
siening impliseer dat die mens sekere inherente vermoëns het wat 'n invloed het op watter ervarings hy of sy sal hê en hoe dit hom sal beïnvloed. Die mens struktureer dus sy eie ervarings (Windmiller, 1980:2).

Een van die vroegste en belangrikste verteenwoordigers van die strukturalistiese beskouings was Jean Piaget, wat in die dertigerjare navorsing gedoen het oor die morele ontwikkeling by jong kinders en adolessente en so verskillende ontwikkelingstadia begin onderskei het. Dit was egter veral Kohlberg wat die werk van Piaget oor die stadia van morele ontwikkeling doelgerig voortgesit het (Windmiller, 1980:2). Dit het vir die voorstanders van hierdie benadering gegaan oor die beredeneringswyse van morele kwessies en die wyse waarop tot waarde-oordele gekom word. Strukturaliste het beweer dat ' $n$ kind se kognitiewe ontwikkeling sy morele ontwikkeling bepaal. Namate kognitiewe strukture meer kompleks word, sal die moontlikheid van 'n meer komplekse beredenering oor morele sake gevolglik ook meer moontlik word. Die opvatting dat morele ontwikkeling die resultaat is van kulturele norme oor wat reg of verkeerd is, word ook deur hierdie denkrigting verwerp (Windmiller, 1980:3). Dit is waarskynlik juis hierdie afwysing van kulturele beïnvloeding wat daartoe lei dat die rol van ouers in die morele ontwikkeling van die kind geringgeskat word binne die raamwerk van 'n strukturalistiese benadering. Die fokus op die invloed van portuurgroepe weerspieël volgens Walker (1999:261) iets van die optimisme van hierdie beskouing, naamlik dat uit die interaksie met gelykes morele insig en volwassenheid as 't ware spontaan sal ontwikkel.

\subsubsection{Die beskouing dat 'n mens sosiaal "leer"}

Die benadering dat 'n mens as 't ware binne jou sosiale omstandighede "leer" en deur die gemeenskap opgevoed word, kan beskou word as 'n direkte uitvloeisel van die ouer filosofiese beskouing waarna hierbo verwys is, naamlik dat die mens 'n skoon lei is waarop die gemeenskap die ervarings van die individu skryf. Dié benaderingwyse het sy oorsprong in die empirisme van John Locke en die behaviourisme van John Watson (Windmiller, 1980:4). Hiervolgens word onder andere geleer dat verskillende instellings soos die gesin en die sosiale klas waartoe mense behoort, asook oorgelewerde kultuurgebruike, 'n rol speel in die proses waardeur individue ervaring van die lewe verwerf.

Soos Windmiller (1980:4) tereg aantoon, ken hierdie benadering meestal die verantwoordelikheid aan ouers toe om hulle kinders se 
morele bewussyn te ontwikkel. Terselfdertyd is hierdie beskouing die grondslag van skoolprogramme in die VSA en ook in Suid-Afrika in ' $n$ vroeëre en veral die huidige politieke bedeling. Hierdie skoolprogramme is/was naamlik daarop ingestel om morele waardes en 'n positiewe burgerskapsingesteldheid aan kinders deur te gee en te benadruk. Nie net formele onderrig nie, maar ook die sosialisering van die kind is gesien as die legitieme verantwoordelikheid en opdrag van die instelling soos die skool (Windmiller, 1980:4).

Die inherente gevaar van hierdie benadering is dat die klem eerder op samelewingsverbande sal val, wat klaarblyklik die taak meer effektief kan verrig. Vir die sosioloog Emile Durkheim was die gesin se vermoë as struktuur en lewensverband té beperk en té persoonlik om dit wat kultuurmatig belangrik is, te kan oordra (Windmiller, 1980:4; vgl ook Turner, 2005:701 en Bouas, 1993:181 oor Durkheim se klem op die kollektiewe bewussyn en die individu se verbintenis aan 'n groep). Durkheim bepleit dat ouers vrywillig van hulle taak en reg in hierdie verband moet afstand doen, ten gunste van die skool.

Die voorstanders van die uitgangspunt dat 'n mens sosiaal "leer", dit wil sê kennis verwerf op grond van blootstelling aan die gemeenskap, sien reëls dus ook as sosiaal en kultuurbepaald en iets wat deur die gemeenskap aan die individu oorgedra of selfs opgedwing word. Die strukturaliste, aan die ander kant, sien reëls as iets wat deur die individu self gegenereer word en universeel van aard is.

\subsubsection{Die psigoanalitiese beskouing}

Freud, wat algemeen aanvaar word as die grondlegger van die psigoanalise, was die eerste navorser wat 'n formele analise van dissipline en die internalisering van waardes gemaak het (Grusec, 1997:6). In terme van die psigoanalitiese benadering lei ouers se afdwinging van waardes op kinders onvermydelik tot gevoelens van afkeer en vyandigheid, maar kinders onderdruk dié negatiewe gevoelens uit vrees vir straf. Die verskynsel dat kinders probeer om skuldgevoelens te vermy, word 'n meganisme wat hulle internalisering van waardes onderlê. Hierdie benadering aanvaar ook dat ouerlike waardes in hulle geheel sonder enige modifikasie deur kinders oorgeneem word (Grusec, 1997:6).

Vir Windmiller (1980:5) is die psigoanalitiese benadering van morele ontwikkeling soortgelyk aan dié benadering se beskouing van die individu: mense word aangedryf deur irrasionele impulse wat beheer 
moet word deur sosiale reëls of verbiedinge. Hierdie benadering tot die morele ontwikkeling van kinders is nie een wat dikwels na vore kom of gevolg word nie. Windmiller (1980:6) beskou dit nogtans om twee redes as van belang:

- Die psigoanalise is die enigste teorie oor morele ontwikkeling waarin die kragte wat die persoonlikheid van die kind vorm, ook 'n meganisme vorm wat die mens moreel beperk en wat die persoonlikheid in stand hou.

- Die psigoanalise vind sy oorsprong tot 'n groot mate in die Bybelse leerstellings oor die erfsonde.

\subsection{Die rol van ouers binne die verskillende modelle}

Soos reeds aangedui is, lê die verskillende benaderingswyses wat bespreek is, wisselende klem op die rol van die ouer. Dit is egter steeds belangrik om hieraan aandag te gee - veral as besin word oor die rol van ouers en die gesin en tot watter mate hierdie bemoeienis kinders se geloof kan laat ontwikkel en vestig.

\subsubsection{Die strukturalistiese beskouing}

Van die drie beskouings wat in hierdie artikel oorsigtelik bespreek is, ken die strukturalistiese benadering aan die ouer die mins belangrike rol toe in die ontwikkeling van morele waardes by die kind. Die invloed van portuurgroepe word egter hoog geskat. Piaget ondersteun byvoorbeeld die siening dat die kind self ' $n$ aktiewe rol speel in sy morele vorming. Hy benadruk dat as die kind interaktief met die omgewing omgaan, hy/sy hulle eie intellektuele en geestestrukture daarstel (Windmiller, 1980:14). Nogtans misken Piaget nie die rol van die ouer in hierdie proses geheel en al nie. Volgens Piaget ken die kind enersyds gesag aan die ouer toe en andersyds verskaf die ouer steeds leiding gedurende die kinderjare, totdat sy rol later deur dié van die portuurgroep oorgeneem word (Windmiller, 1980:14).

Kohlberg, as navolger en uitbouer van Piaget se idees (Windmiller, 1980:18), ken 'n nog kleiner rol aan die ouer toe en beskou die rol van die ouer nie as van kritiese belang in die morele vorming van die kind nie. Walker (1999:261) skryf Kohlberg se geringskatting van die ouerlike rol en die belangriker rol wat hy aan portuurgroepe toeken, juis toe aan die feit dat Kohlberg die waarde van die Israeliese kibboets-stelsel besonder hoog aanslaan. 


\subsubsection{Die beskouing dat 'n mens sosiaal "leer"}

Hierdie beskouing impliseer dat 'n mens sosiaal leer en gevorm word binne die gemeenskap waarin jy geplaas is. Van die drie beskouings wat reeds genoem is, is hierdie beskouing ongetwyfeld dié een wat aan ouers die belangrikste en mees "normale" rol toeken by die ontwikkeling van kinders se morele waardes. Anders as by die strukturalistiese benadering, is daar egter nie so ' $n$ duidelike groep aantoonbare teoretici wat 'n oorheersende rol speel by die formulering van hierdie benadering nie.

Die veronderstelling wat hierdie benadering onderlê, is dat kinders op 'n betreklike jong leeftyd hulle ouers se waardes aanleer deur 'n proses van modellering en nabootsing. Waardes word op grond van hierdie prosesse gaandeweg geïnternaliseer en op positiewe of negatiewe wyses versterk (Windmiller, 1980:22). Die rol wat ouers in dié vestiging speel, is voor die hand liggend en word in tersaaklike vakliteratuur veral aan die hand van drie aspekte onderskei (Windmiller, 1980:22):

- Die direkte modelleringsrol wat die ouer speel.

- Die stelsel van beloning en straf wat toegepas word.

- Die algemene impak wat ouers se optrede op die kind het.

\subsubsection{Die psigoanalitiese beskouing}

Soos reeds gestel is, het die grootste gedeelte van die psigoanalitiese benadering te doen met Freud se grondliggende idees. Van kernbelang in hierdie opsig is die konsep van die superego, oftewel die gewete. Die individu het naamlik sy unieke eienskappe aan die ouers te danke en aanvaar hierdie waardestelsel om verskillende redes: op grond van sy/haar liefde vir die ouer, op grond van die gevoel dat hierdie waardes na buite gereflekteer moet word, of uit vrees dat hy of sy andersins die liefde van die ouers sal verloor (Windmiller, 1980:25). In finale instansie lê die oorsprong van alle waardes, moreel of andersins, in die vroeë verhouding tussen ouer en kind (Windmiller, 1980:26).

\subsection{Determinante by effektiewe waarde-oordrag}

Dit is bo alle twyfel duidelik dat die ouers en gesin 'n rol speel in die morele vorming van kinders - watter teoretiese beskouing ook al in hierdie verband toegepas word. Ook al meen sekere denkers dat die rol van ouers en gesin nie noodwendig belangriker is as dié van portuurgroepe nie, kan die gesinsrol op geen wyse buite rekening 
gelaat word nie. Gevolglik is 'n belangrike opvolgvraag die volgende: watter omstandighede binne 'n gesin sal veral die suksesvolle oordrag van waardes waarborg? Dit is derhalwe noodsaaklik om die omstandighede wat effektiewe oordrag fasiliteer, te ondersoek. Onderstaande faktore verteenwoordig enkele omstandighede wat noodsaaklik is vir die effektiewe oordrag van waardes.

\subsubsection{Gesinskohesie}

Verskillende studies benadruk die noue verwantskap tussen gesinskohesie (gesinsbinding) en die effektiewe waarde-oordrag van ouer na kind. Terselfdertyd kan ' $n$ verband tussen kohesie en 'n meer gevorderde morele oordeel waargeneem word (White, 2000:78). Een van die verklarings vir dié verskynsel lê waarskynlik in die konsep van gesinsgrense. As gesinsgrense meer geslote is, het die rol van ouers en hulle voorbeeld 'n groter impak op die vorming van waardes. As gesinsgrense meer deurdringbaar is, neig die relatiewe rol van die gesin om te verminder teenoor dié van die buitewêreld.

In 'n empiriese studie met meer as 500 gesinslede in Australië het White (2000:87) ondersteuning gevind vir die hipotese dat adolessente wat hulle gesinne ervaar as sterk onderling verbonde en waar daar warmte is, ' $n$ groter rol aan ouers toeken in die vorming van hulle morele waardes.

\subsubsection{Aanpasbaarheid binne die gesinstruktuur}

Net soos gesinskohesie is die vermoë van 'n gesin om sy gesagstruktuur, onderhandelingstyl en verhoudingsreëls aan te pas in reaksie op verskillende situasies en die spanning wat ontwikkeling teweegbring, 'n fasiliterende omstandigheid. 'n Gesin se aanpasbaarheid is ook ' $n$ positiewe voorspeller van die wyse waarop kinders ouerlike waardes sal navolg (White, 2000:79). Binne gesinne wat plooibaar en sensitief vir verandering is, is daar meer geleentheid vir die uiting van menings, die geleentheid om 'n verskeidenheid sienings te ervaar en die geleentheid om te leer wat samewerking behels. Daarteenoor kry adolessente binne meer rigiede gesinne minder geleentheid om 'n verskeidenheid rolle en standpunte te ervaar en daardeur verryk te word, soos White (2000:87) deur middel van haar studie bevestig. 


\subsubsection{Gesinskommunikasie en ooreenstemming tussen ouer en adolessent}

Wat hierdie aspek betref, gaan dit veral oor positiewe kommunikasievaardighede soos empatie, die vermoë om aandagtig te luister en ondersteunende kommentaar te lewer (White, 2000:79). Indien 'n saak vir ouers belangrik is en dit sigbaar en waarneembaar is, verteenwoordig hierdie houding 'n belangrike determinant om ouers en kinders te laat ooreenstem oor waardes (White, 2000:79). Gereelde en oop besprekings oor sake van belang is bevorderlik vir sodanige ooreenstemming. Adolessente wat binne die gesin 'n negatiewe kommunikasiestyl ervaar, byvoorbeeld 'n houding van vyandigheid en kritiek, se kanse is baie kleiner om hulle ouers se waarde-oordele oor te neem.

In samehang met hierdie bevindings moet die werk van Kuczynski et al. (1997) in ag geneem word waarin daar klem gelê word op die voordeel van 'n tweerigtingbenadering in die oordra van waardes. 'n Tweerigtingbenadering funksioneer naamlik as 'n imperatief én as 'n ontledingsmaatstaf vir gesinne. Kuczynski et al. (1997:23) toon aan hoe die dominante metafoor in die proses van waarde-oordrag dikwels ongelukkig dié van eenrigtingverkeer is waar min aandag gegee word aan die invloed wat kinders self op hulle sosialisering kan uitoefen. Ook word min erkenning gegee aan kinders se eie bydrae in die proses. Ouers wat besorg is oor die oordrag van waardes aan kinders, kan hulle aandeel meer suksesvol uitvoer in 'n situasie waarin hulle die rol van kinders in ag neem, eerder as om dit te ignoreer (Kuczynski et al., 1997:44). Ook Steyn (1996:146) beklemtoon dat die belangrikheid om groter klem te lê op tweerigtingverkeer tussen ouers en kinders binne die SuidAfrikaanse konteks meer en meer na vore kom.

'n Interessante bevestiging vir die siening dat goeie kommunikasie binne die gesin bevorderlik is vir waarde-oordrag en -ooreenstemming, is in 'n studie op die politieke terrein. Jennings et al. (1999:13) het naamlik in hulle bestudering van die oordrag van politieke affiliasie by verskillende geslagte Amerikaanse ouers en kinders gevind dat die duidelikheid en konsekwentheid waarmee ouers riglyne vir politieke denke oordra, positief korrelleer met die ooreenstemming tussen ouer en kind. 


\section{Die oordrag van godsdienstige waardes - die ouer se rol}

In die vorige afdeling het dit spesifiek gegaan oor waardevorming en -oordrag by die kind in sy verskillende ontwikkelingstadia en oor die mindere of meerdere rol van die ouer in dié proses. In hierdie afdeling word gefokus op 'n meer toegespitste en spesifieke aspek, naamlik die rol van die ouer by die vorming en oordrag van godsdienstige waardes, inhoud en affiliasie by die kind. Wat die oordrag van morele waardes betref, is daar uiteenlopende menings oor die omvang van die ouer se rol. Wat die oordrag van godsdienstige waardes betref, is daar egter betreklik groot ooreenstemming oor die omvang van die ouers se rolle. Boyatzis en Janicki (2003:252) stel dat daar heelwat invloede is wat meewerk in die religieuse vorming van die kind en dat, soos die Engelse gesegde dit stel, "it takes a village" om die kind te sosialiseer, maar dat die ouers in hierdie opsig die "first village" is.

Dit is opmerklik dat op die gebied van algemene waardevorming heelwat konseptuele modelle en teorieë ontwikkel wat met mekaar meeding in die verklaring van verskillende aspekte van godsdiensoordrag. In teenstelling hiermee is dit opmerklik dat op die gebied van spesifiek godsdiensoordrag baie empiriese navorsing gedoen is oor die rol van die ouer:

- Bjarnason (1998) toets in sy bestudering van 'n aantal Yslandse tieners se godsdiensbelewing veral die Durkheim-model van sosiale samehang en ondersteuning soos dit betrekking het op die godsdiensbelewing en -ondersteuning van die betrokkenes.

- Sowel die studies van Dickie et al. (1997) en Tamayo en Desjardins (1976) berus op opnames wat onder verskillende groepe kinders gedoen is. In hierdie empiriese navorsing is gekonsentreer op die samehang tussen kinders se beeld van God aan die een kant, en hulle geloof en verhouding met hulle ouers aan die ander kant.

- Boyatzis en Janicki (2003) het die effek van ouers en kinders se tweerigtingkommunikasie oor godsdiens nagegaan, terwyl Giesbrecht (1995) spesifiek ouerskapstyle en die invloed daarvan op adolessente se godsdienstige verbintenis ondersoek het.

- Kelley en De Graaf (1997) gebruik inligting uit vyftien verskillende lande om die invloed van ouersosialisering op geloof te bepaal, terwyl die studie van Hayes en Pittelkow (1993) spesifiek gefokus het op Australiese kinders en gegewens wat in Australië verkry is. 
- Die studies van Francis en Gibson (1993), Hoge et al. (1982) en Dudley en Dudley (1986) is meer algemeen empiries van aard en handel oor die verwantskap van ouers en geloofsoordrag, terwyl Okagaki en Bevis (1999) hulle studie meer spesifiek rig op ouers se invloed op die geloofsbelewing van dogters.

- Die plaaslike studie van Steyn (1996) is nie uitsluitlik gerig op die verband tussen ouerlike waardes, dié van kinders en die oordrag daarvan nie, maar gee wel deeglik aandag aan die ouerkindverhouding.

Daar is dus ' $n$ verskeidenheid empiriese studies waarvan bostaande voorbeelde 'n seleksie verteenwoordig. Soos dit reeds gestel is, bly dit egter opmerklik dat die sentraliteit van ouerlike invloed algemeen in dié empiriese studies aanvaar word.

\section{1 'n Algemene model vir die omskrywing van godsdiens- belewing}

Bjarnason (1998:741) toon aan dat binne die verskeidenheid konsepte oor die positiewe invloed van godsdiens in die lewe van die individu en die gemeenskap, twee benaderings veral na vore kom:

- Eerstens die siening dat die godsdienstige gemeenskap 'n belangrike rolspeler is om die individu se inskakeling in die gemeenskap te integreer en te beheer.

- Tweedens lê hierdie benadering klem op godsdienstige opvattings as singewend vir die individu se opvattings oor die wêreld en die werklikheid.

Bjarnason gebruik in hierdie verband veral die konsepte van Durkheim om 'n model van sosiale integrasie deur middel van ondersteuning en godsdiensoordrag te skep.

Kernagtig kom hierdie model op die volgende neer: gemeenskaplike betrokkenheid en identiteit verskaf aan mense 'n sin van samehang en betekenisvolheid wat bydra tot hulle welsyn (Bjarnason, 1998:743). Hierdie effek is net moontlik indien die gemeenskap as 'n sinvolle eksterne realiteit waargeneem word. As hierdie sinvolle persepsie van die gemeenskapsrol nie bestaan nie, tree vervreemding in, wat nie bloot impliseer dat mens van die gemeenskap vervreem raak nie, maar ook dat jy onttrek van die belewing van 'n gemeenskap (Bjarnason, 1998:743). Die rol van gemeenskaplike godsdiensbelewing is tweërlei van aard. 
- Enersyds skep dit 'n eksterne realiteit wat as objektief en voorspelbaar waargeneem kan word en sodoende stabiliteit aan die individu verskaf.

- Andersyds speel gemeenskaplike godsdiensbelewing 'n rol as ' $n$ beperking (constraint). Die individu beleef hierdie gemeenskaplike godsdiensbelewing asof hy/sy 'n persoonlike verpligting teenoor die eise en verwagtinge van die gemeenskap het.

Soos dit spesifiek deur Bjarnason (1998:746) op adolessente toegepas word, is die raamwerk van gesin en ouers en die godsdiensbelewing en -oordrag daarbinne 'n spesifieke bron van integrasie in en regulering deur die gemeenskap. Integrasie is inderwaarheid die sentrale konstruk in die opvattings van Durkheim (Bjarnason, 1998:746). Vir die adolessent geskied integrasie hoofsaaklik op twee maniere: die wyse waarop ondersteunende en versorgende ouers 'n ooreenstemmende beeld van God by die adolessent skep en die wyse waarop die reëls wat ouers neerlê, die beeld van 'n sinvolle eksterne realiteit bevestig.

Die uitgangspunte van hierdie model word bevestig deur Bjarnason se empiriese studie. Adolessente se ervaring van 'n eksterne sosiale werklikheid word sterk en positief beïnvloed deur ouers se ondersteuning en godsdienstige betrokkenheid (Bjarnason, 1998: 72). Hierdie ervaring van 'n eksterne sosiale werklikheid lei terselfdertyd daartoe dat kinders wat hulle ouers as sorgsaam en ondersteunend ervaar, groter godsdienstige betrokkenheid aan die dag lê. Volgens Bjarnason bestaan die moontlikheid inderdaad dat die algemene welsyn van adolessente beïnvloed word op grond van godsdienstige meganismes wat tot stand kom deur hulle verhouding met hulle ouers (Bjarnason, 1998:752).

\subsection{Relatiewe invloed van ouers}

Dit is reeds vermeld dat 'n groot aantal empiriese studies oor die oordrag van godsdienstige waardes bestaan. Juis die uitvoerige aard van sodanige empiriese gegewens bemoeilik die keuse tussen resultate wat in verskillende kleiner opsigte teenstrydige rigtings aandui. Twee aspekte van die relatiewe invloed van ouers onderling en in vergelyking met ander verbande, behoort egter vermeld te word. 


\subsubsection{Vaders en moeders se onderskeie rolle}

Meer as een van die studies vestig die aandag op die belangrike plek van moeders in die godsdienstige vorming van kinders. In hulle studie oor die aard en invloed van godsdiensbepaalde kommunikasie tussen ouers en kinders lê Boyatzis en Janicki (2003:263, 265) klem op die wyse waarop veral moeders 'n rol gespeel het in dié ondersoek. Dit was veral moeders wat die meeste gesprekke met kinders oor godsdienstige onderwerpe gevoer het. Die moeders was ook grootliks verantwoordelik vir die voltooiing van die inskrywings met 'n verslag oor daaglikse gegewens wat in die studie gebruik is - waarskynlik vanweë beroepspatrone wat hulle meer geleentheid gee om met kinders te kommunikeer.

Ook Francis en Gibson (1993:250) en Dudley en Dudley (1986:13) bevind in hulle studies dat moeders se praktiese godsdiensbeoefening en godsdiensbepaalde waardes onderskeidelik beter voorspellers is van hulle kinders se godsdiensontwikkeling as dié van vaders.

\subsubsection{Ander verbande se invloed}

In teenstelling met wat vroeër gestel is aangaande die strukturalistiese siening van die aanleer van waardes, vind 'n mens in tersaaklike vakliteratuur oor die oordrag van godsdienstige waardes geen verskil in siening oor die primêre posisie van ouers en die gesin nie. Dit beteken egter nie dat daar nie ruimte gelaat word vir die invloed van ander lewensverbande in die proses van waardeoordrag aan kinders nie.

\section{- Nasionale konteks en invloede}

Veral Kelley en De Graaf (1997:654-655) vestig die aandag op nasionale invloede. Wat die vorming van godsdienstige waardes betref, is hulle selfs bereid om in sommige gevalle 'n groter rol toe te ken aan die nasionale konteks as aan gesinsagtergrond (Kelley \& De Graaf, 1997:654). Hulle skryf hierdie invloede wat uitgaan van die nasionale konteks in die eerste plek direk toe aan die beskikbare groep vriende, kollegas en potensiële huweliksmaats wat 'n invloed kan uitoefen. Die nasionale konteks kan uiteraard in 'n land, wat erkenning gee aan godsdienstige waardes, 'n sterker positiewe invloed uitoefen as in 'n land waar sekulêre waardes oorheers. In die tweede plek oefen nasionale konteks ook 'n invloed uit op ouers se vermoë om godsdienstige waardes aan hulle kinders oor te dra. In sekulêre gemeenskappe word die posisie van nie-godsdienstige ouers versterk, terwyl dié van godsdienstige ouers nie verswak word 
nie en hulle steeds in staat is om hulle kinders van die invloede van die sekulêre gemeenskap te isoleer. Ironies genoeg is sekulêrgeoriënteerde ouers in godsdienstige gemeenskappe tot 'n mindere mate in staat om hulle kinders van die invloed van die gemeenskap af te skerm (Kelley \& De Graaf, 1997:655)

\section{- Skoolkonteks en portuurgroep}

Die aard van gegewens oor die invloed van skoolkonteks en portuurgroep in die geraadpleegde bronne is nie ondubbelsinnig nie. Terwyl die primaat van ouers en gesinsverband steeds gehandhaaf word, is daar 'n duidelike aanvaarding dat vriende en skoolverband ook 'n invloed kan uitoefen. Veral Regnerus et al. (2004) gee aandag aan hierdie invloede. Hy toon aan dat as die kerkbywoning van vriende ongereeld en min is, dit 'n duidelike invloed op die kerkbywoning van jeugdiges het (Regnerus et al., 2004:34). Insgelyks is daar 'n duidelike verband tussen die algemene vlak van godsdienstigheid in 'n skool en die godsdienstige ingesteldheid van kinders in dié skool (Regnerus et al., 2004:35). Hierdie skrywers toon egter aan dat die invloed van ouers ook op hierdie aspek, en die gevolglike seleksie-effek, nie onderskat moet word nie. Dit is baie waarskynlik dat ouers wat bogemiddeld godsdienstig is, hulle kinders sal aanmoedig om vriende te maak met kinders wat ook godsdienstig is (Regnerus et al., 2004:35). Ook Cornwall (1988:227) bevestig die invloed van die portuurgroep op die godsdienstige ontwikkeling van kinders. Cornwall maak egter onmiddellik melding van ouers se invloed op hul kinders se godsdienstige ontwikkeling, omdat hulle hul kinders se belange gewoonlik na aktiwiteite en netwerke "kanaliseer" wat die godsdienstige waardes, wat in die huis oorgedra is, verder kan versterk.

\subsection{Prosesse wat bydra tot godsdienstige ontwikkeling}

Heelwat navorsing word gedoen oor die relatiewe invloed van ouers en kinders onderling en in verhouding tot ander verbande. Dit is egter ook belangrik om nie net aandag te gee aan die dat van godsdienstige ontwikkeling nie, maar ook aan die hoe. Cornwall (1988:227-228) onderskei in haar studie drie bydraende prosesse waardeur ouers gestalte gee aan die godsdienstige ontwikkeling van hulle kinders:

\section{- Die daarstel van religieuse betekenis}

In die ontwikkeling van ' $n$ wêreldbeskouing of betekenissisteem is narratiewe oor die kompleksiteite van die omringende werklikheid, of gesprekke om betekenis aan die werklikheid te gee, uiters belangrik. 
Sulke narratiewe of gesprekke stel die mens (en dus ook die kind) in staat om die wêreld en die wyse waarop dinge daarin saamhang, te verstaan. Die gesinsomgewing is die fondamente waarop die kind sy wêreldbeskouing bou. Hoe meer godsdiensgeoriënteerd hierdie gesinsomgewing is, hoe solieder dus die godsdienstige vorming van die kind.

\section{- Die modellering van godsdienstige gedrag}

Die kind moet nie slegs 'n bepaalde werklikheidsbeskouing ontwikkel en die sin en ontwikkeling van hierdie omringende wêreld begryp nie; die kind moet ook in staat wees om in te skakel in 'n bepaalde godsdienstige groepering. Hierdie inskakeling impliseer ook dat die kind gaandeweg moet begryp wat die groepslede se verwagting is aangaande aanvaarde houdings en optrede. Alhoewel hierdie kennis kan voortvloei uit die besondere wêreldbeskouing wat by die kind gevorm is, word 'n mens se werklikheidsiening veral geskoei op die voorbeeld en optrede van meer ervare lede van die groep - veral die voorbeeld van die ouers met wie die kind in daaglikse wisselwerking is. Martinson en Martinson (1998:69) sien die wyse waarop ouers regverdige en samewerkende gedrag modelleer, juis as die meganisme waardeur kinders in ervarings en verhoudings geplaas word wat hulle karakter vorm.

\section{- Die "kanalisering" van waardes}

Vroeër is reeds verwys na die wyse waarop ouers deur kanalisering bepaal watter invloed ander verbande op die godsdienstige ontwikkeling van die kind het. Godsdienstige groepe is - soos alle ander groepe - daarop ingestel om sy lede aan te moedig om hulle toe te wy aan die doelwitte van die groep (Cornwall, 1988:228), omdat die lewenskragtigheid en oorlewing van die groep daarvan afhang. Die aanmoediging en vorming van bande binne die groep, of met individue van soortgelyke oortuiging, is derhalwe van die grootste belang. Groepsverbondenheid en die versterk van bande binne die groep is immers een van die primêre wyses waarop ouers die vorming en ontwikkeling van hulle kinders, binne 'n bepaalde oortuigingsraamwerk, aanmoedig.

\subsection{Faktore wat bydra tot godsdiensontwikkeling in gesins- verband}

Wanneer die godsdienstige ontwikkeling van die kind beoordeel word, is dit vanselfsprekend dat nie net gelet moet word op die dat en die hoe van die proses nie, maar ook op die waarom daarvan. Laasgenoemde aspek, naamlik waarom moet 'n sin vir godsdiens 
ontwikkel, sluit ook die besinning in oor faktore binne die gesinsopset wat bevorderlik of belemmerend op die godsdienstige ontwikkeling van die kind kan inwerk. Hoge et al. (1982:576-578) het in hulle studie vyf sodanige invloede gevind, wat in mindere of meerdere mate ook deur ander studies bevestig is:

\section{- Ouerkenmerke}

Demografiese veranderlikes in ouers se situasie bepaal waarskynlik in ' $n$ mindere mate die godsdienstige ontwikkeling van die kind. Alhoewel Hoge et al. (1982) na 'n aantal verskillende aspekte gekyk het, is slegs een daarvan positief verbind met die ontwikkeling van kinders: hoe jonger die ouers was, hoe effektiewer het waardeoordrag tussen ouers en hulle kinders plaasgevind.

\section{- Ooreenstemming tussen ouers}

Indien ouers saamstem oor godsdienstige sake, werk dit positief in op waarde-oordrag en godsdienstige vorming. Ook wanneer ouers saamstem oor ouerskapstyl en 'n gesagvolle en ondersteunende ouerskapstyl gehandhaaf word, is dit bevorderlik om intrinsieke godsdienstige toewyding te bevorder (Giesbrecht, 1995:236). Wanneer ouers rusie maak oor opvoedingsaspekte, is die effek uiteraard negatief - nie net omdat die ouers se benaderingwyses nie ooreenstem nie, maar ook omdat kinders in hulle ouers se gedragswyse 'n (negatiewe) model vir verskil vind (Spilka et al., 1985:84).

\section{- Ouers se godsdiens}

Die Hoge-studie (Hoge et al., 1982:577) het bevind dat wanneer die ouers se godsdienstige betrokkenheid (creedal assent) in 'n beduidende mate aanwesig is, die oordrag van waardes na hulle kinders suksesvol is - veral in die geval van dogters.

\section{- Godsdienstige sosialisering}

Ouers se erns met die godsdienstige sosialisering van hulle kinders en die druk wat hulle bereid is om op kinders uit te oefen om hulle daarin na te volg, speel 'n besliste rol in kinders se godsdienstige sosialiseringsproses. Ook die mate waartoe ouers met hulle kinders oor godsdiens praat, het veral in die geval van dogters beduidend tot suksesvolle waarde-oordrag gelei. Hierdie tipe benadering het egter in die geval van seuns nie voorspelbare waarde gehad nie (Hoge et al., 1982:577). Bjarnason (1998:750) meen dat wanneer ouers reëls neerlê, dit tot groter godsdienstige betrokkenheid by hulle kinders lei. Martinson en Martinson (1998:68) beklemtoon op 
hulle beurt die daarstelling van 'n positiewe emosionele klimaat binne 'n gesin, ten einde positiewe waardes aan kinders oor te dra.

\section{- Verhouding met ouers}

Soos verwag kan word, is die ouer-kindverhouding die een veranderlike wat 'n negatiewe invloed op waarde-oordrag kan impliseer. Alhoewel die Hoge-studie nie verwys na die invloed van die ouer-kindverhouding en die bepalende rol hiervan op die kind se Godsbeeld nie, is dit tog deeglik ter sake wanneer besin word oor godsdiensontwikkeling. Dickie et al. (1997:31) het in hulle studie bevind dat wanneer kinders hulle ouers as versorgend sien en ervaar, dieselfde eienskappe vasgelê word in die beeld van God wat by die kinders gevestig word. Ook Bjarnason (1998:750) bevestig dat ouers se ondersteuning positief inwerk op die kind se belewing dat God ondersteunend teenwoordig is in hulle lewens.

\section{Gevolgtrekkings}

Die belang en rol van die gesin binne 'n breër gemeenskapstruktuur en in die vorming en inkleding daarvan, is onbetwisbaar van belang. Die wyse waarop ouers instrumenteel is in die vorming van hulle kinders deur die oordrag van gebruike, houdings en waardes, word algemeen aanvaar. Tog moet die wyse waarop waarde-oordrag plaasvind, ook gesien word as relatief ondergeskik aan ander lewensverbande en moet die oordragproses ook binne hierdie raamwerk verduidelik word. Wetenskaplike sienings oor die rol van die gesin verskil soms, maar hierdie verskil in sienings trek dikwels saam in kleiner aspekte van die ouerlike rol (moontlik selfs die positiewe of negatiewe aspekte van ouers se optrede). Hierdie verskil in sienings betwyfel egter nooit die wesenlike van die ouer se rol nie.

Met onderstaande gevolgtrekkings is gepoog om sekere tendense op grond van die voorafgaande bespreking op oorsigtelike wyse uit te lig. Hierdie gevolgtrekkings moet egter nie as geïsoleerde stellings gelees word nie; die afleidings behoort breër uitgewerk te word. Gelowige ouers behoort hierdie afleidings in samehang met Skrifperspektiewe te beoordeel.

\section{- Veranderende sienings oor die konsep van gesin}

Daar moet baie versigtig omgegaan word met besinnings oor die gesin, en veral die kerngesin as konsep. Veral moet daarteen gewaak moet om persepsies oor gesin en kerngesin te verhef tot tydlose konsepte. Op grond van Skrifuitsprake kan geen twyfel 
bestaan oor die belangrikheid van die huwelik en die verhouding tussen ouer en kind nie. Die struktuur wat breedweg as die gesin bekend staan, het egter deur die eeue en in verskillende kultuurgroeperings in baie opsigte gewissel en van vorm verander en dit verander nog steeds. Dit sal daarom verstandig wees om telkens te konsentreer op die wesenlike van persoonlike verhoudings, waarvan dié tussen ouer en kind primêr is, eerder as om te konsentreer op die wisselende strukture waarbinne sodanige verhoudings bestaan.

\section{- Die invloed van die filosofiese tydsgees, maatskaplike opset en kerklike bedieningswyse}

Net soos met die gesin, is die wetenskaplike bestudering van gesin as konsep ook tydsgebonde en dit word bepaal deur filosofiese stromings, tydsgees en dampkring - nie net deur die filosofiese beskouings wat van tyd tot tyd oorheersend is nie, maar ook deur die praktiese omstandighede van gemeenskappe waarbinne sodanige bestudering plaasvind (veral ekonomiese en sosiale omstandighede). Veral die kerk mag nie toelaat dat die klem in sy bedieningswerk buitensporig op 'n "ideale" vorm van gesinsopset, naamlik die kerngesin, soos dit ontwikkel het in die Westerse wêreld, geplaas word nie. Sodanige beklemtoning kan lei tot die nadeel van die meer gemarginaliseerde lede van die gemeenskap, wat om 'n verskeidenheid redes buite so 'n verband staan.

\section{- Groter klem op individualisme}

Die kerk en die gesin en 'n veelheid ander verbande, ontkom nie aan die gevolge van 'n steeds groter geneigdheid tot individualisme en 'n afkeer van gebondenheid nie. Sulke tendense moet nie sonder meer afgewys word nie, omdat daarin ook 'n basis van vernuwing en kritiese oorweging van die bestaande lê. Veral ouers moet egter daarvan bewus wees dat dit juis binne die intieme binding van die gesin, 'n groter verpligting op hulle plaas om leiding te gee.

\section{- Die gesin én ander lewensverbande}

Oor die primêre posisie van die gesin in die waardevorming van kinders bestaan tot 'n groot mate eenstemmigheid. Tog moet die verband van die gesin en ander samelewingsverbande en verhoudings waarbinne gesinslede hulle bevind, nie geringgeskat word nie. Die gesin is nie ' $n$ doel op sigself nie, maar is saam met ander verbande diensbaar in die totale vorming van die individu, om sodoende haar/sy verantwoordelikheid ten volle te kan uitleef. 
Daarom behoort die gesinsrol nie ander regmatige verbintenisse te oorheers of selfs uit te sluit nie.

Binne die gesin self is daar egter besliste bepalende faktore waarvan die invloed onmiskenbaar en selfs ononderhandelbaar is:

- Die struktuur van die gesin, die onderlinge verbondenheid van gesinslede en hul aanpasbaarheid teenoor mekaar.

- Ouerskap impliseer nie bloot 'n vormlose en "leë" teenwoordigheid nie, maar die moeder en vader het elkeen 'n wedersyds ondersteunende rol in hulle kinders se vorming.

- 'n Gemaklike en liefdevolle vehouding tussen ouers en kinders en positiewe onderlinge kommunikasie is 'n voorvereiste vir waardeoordrag, die vestiging van 'n godsdiensbepaalde lewenswyse en die ontwikkeling van sinvolle godsdiensbelewing. Binne die raamwerk van positiewe kommunikasie kan ouerleiding ook dien om kinders se (godsdienstige) belange te kanaliseer in rigtings waarin hierdie godsdienssin verder gevestig en bevestig kan word.

- 'n Positiewe gesindheid en ouers se eie geloofsoortuiging is noodsaaklik om waardes en die begrip van godsdienssin effektief aan kinders oor te dra. By kinders word 'n positiewe Godsbeeld sterk gekoppel aan die beeld wat hulle van hulle ouers het. Ouers se modelleringsfunksie kan dus ook in hierdie opsig nie onderskat word nie.

\section{Slot}

Ouers se modelleringsfunksie in die vestiging van hulle kinders se godsdienssin, behoort deur 'n gelowige nie slegs gesien te word as 'n rol wat bepaal word deur die hier en die nou nie. Die vestiging van godsdiensbepaalde patrone en die begrip vir 'n mens se ewigheidsroeping verteenwoordig 'n vertikale dimensie in enige ouer se opvoedingstaak. Vanuit hierdie perspektief is "die oordra van waardes" dus net die beginpunt van 'n lang proses om kinders se geloof te vestig en te anker.

\section{Geraadpleegde bronne}

BJARNASON, T. 1998. Parents, religion and perceived social coherence: a Durkheimian framework of adolescent anomie. Journal for the Scientific Study of Religion, 37(4):742-754.

BOUAS, M.J. 1993. The three R's of moral education: Emile Durkheim revisited. The Educational Forum, 57(2):180-185. 
BOYATZIS, C.J. \& JANICKIE, D.L. 2003. Parent-child communication about religion: survey and diary data on unilateral transmission and bi-directional reciprocity styles. Review of Religious Research, 44(3):252-270.

CORNWALL, M. 1988. The influence of three agents of religious socialization: family, church and peers. (In Thomas, D.L., ed. The religion and family connection: social science perspectives. Provo: Religious Studies Center, BYU. p. 207-231.)

DICKIE, J.R., ESHLEMAN, A.K., MERASCO, D.M., SHEPARD, A., VANDER WILT, M. \& JOHNSON, M. 1997. Parent-child relationships and children's images of God. Journal for the Scientific Study of Religion, 36(1):25-43.

DUDLEY, R.L. \& DUDLEY, M.G. 1986. Transmission of religious values from parents to adolescents. Review of Religious Research, 28(1):3-15.

FRANCIS, L.J. \& GIBSON, H.M. 1993. Parental influence and adolescent religiosity: a study of church attendanc and attitude toward Christianity among adolescents 11 to 12 and 15 to 16 years old. The International Journal for the Psychology of Religion, 3(4):241-253.

GIESBRECHT, N. 1995. Parentying style and adolescent religious commitment. Journal of Psychology and Christianity, 14(3):228-238.

GRUSEC, J.E. 1997. A history of research on parenting strategies and children's internalization of values. (In Grusec, J.E. \& Kuczynski, L., eds. Parenting and children's internalization of values. New York: Wiley. p. 322.)

HAYES, B.C. \& PITTELKOW, Y. 1993. Religious belief, transmission, and the family: an Australian study. Journal of Marriage and the Family, 55(3):755766.

HOGE, D.R., PETRILLO, G.H. \& SMITH, E.I. 1982. Transmission of religious and social values from parents to teenage children. Journal of Marriage and the Family, 44(3):569-580.

JENNINGS, M.K., STOKER, L. \& BOWERS, J. 1999. Politics across generations: family transmission reexamined. [Berkeley]: Institute of Governmental Studies. (Working Paper 2001-15.) www.igs.berkeley.edu/ publications/workingpapers Date of access: 18 June 2004.

KELLEY, J. \& DE GRAAF, N.D. 1997. National context, parental socialization, and religious belief: results from 15 nations. American Sociological Review, 62(4):639-659.

KNAFO, A. \& SCHWARTZ, S.H. 2003. Parenting and adolescents' accuracy in perceiving parental values. Child Development, 74(2):595-611.

KUCZYNSKI, L., MARSHALL, S. \& SCHELL, K. 1997. Value socialization in a bidirectional context. (In Grusec, J.E. \& Kuczynski, L., eds. Parenting and children's internalization of values. New York: Wiley. p. 23-50.)

MARTINSON, R. \& MARTINSON, S.A. 1998. Work of families: roles of families. (In Anderson, H., Browning, D., Evison, I.S. \& Van Leeuwen, M.S. The family handbook. Louisville: Westminster John Knox. p. 63-70.)

OKAGAKI, L. \& BEVIS, C. 1999. Transmission of religious values: relations between parents' and daughters' beliefs. The Journal of Genetic Psychology, 160(3):303-318.

REGNERUS, M.D., SMITH, C. \& SMITH, B. 2004. Social context in the development of adolescent religiosity. Applied Developmental Science, 8(1):27-38.

SPILKA, B., HOOD, R.W. \& GORSUCH, R.L. 1985. The psychology of religion: an empirical approach. Englewood Cliffs: Prentice-Hall. 
STEYN, A.F. 1996. Values that support quality marital and family life. South African Journal of Sociology, 27(4):143-147.

TAMAYO, A. \& DESJARDINS, L. 1976. Belief systems and conceptual images of parents and God. The Journal of Psychology, 92:131-140.

TURNER, S.P. 2005. Durkheim, Emile. (In Kempf-Leonard, K., editor-in-chief. Encyclopedia of social measurement. Volume 1. Amsterdam: Elsevier. p. 699-704.)

WALKER, L.J. 1999. The family context for moral development. Journal of Moral Education, 28(3):261-264.

WALKER, L.J., HENNIG, K.H. \& KRETTENAUER, T. 2000. Parent and peer contexts for children's moral reasoning development. Child Development, 71(4):1033-1048.

WHITE, F.A. 2000. Relationship of family socialization processes to adolescent moral thought. The Journal of Social Psychology, 140(1):75-91.

WHITE, F.A. \& MATAWIE, K.M. 2004. Parental morality and family processes as predictors of adolescent morality. Journal of Child and Family Studies, 13(2):219-233.

WINDMILLER, M. 1980. Introduction. (In Windmiller, M., Lambert, N. \& Turiel, E. Moral development and socialization. Boston: Allyn \& Bacon. p. 1-33.)

\section{Kernbegrippe:}

gesinsbinding

godsdiensontwikkeling: rol van ouers

modellering: ouers se rol as opvoeders

sosiale konteks

waarde-oordrag

\section{Key concepts:}

family cohesion

modelling: parents' role as educators

religious development: parental role

social context

values: transmission of 
